\section{Improved Rooting of Gisela-5 Softwood Cuttings following Banding and IBA Application}

\author{
Hatice Gulen ${ }^{1}$ \\ Department of Horticulture, Uludag University, Gorukle, 16059, Bursa, Turkey
}

Yasar Erbil

Atatürk Central Horticultural Research Institute, Yalova, Turkey

\author{
Atilla Eris \\ Department of Horticulture, Uludag University, Gorukle, 16059, Bursa, Turkey
}

Additional index words. Gisela-5 (P. cerasus x P. canescens- 148/2), rooting, etiolation, banding, IBA

\begin{abstract}
A stock plant etiolation treatment was tested to improve rooting of the important cherry rootstock Gisela-5. To create the etiolation effect, at the beginning of the growing season, banding (blanching) was initiated on stock plants by placing black plastic tape at the base of new shoots for 6 or 10 weeks. Cuttings were excised so that the banded area was at the cutting base. IBA was applied at two concentrations (5 and $10 \mathrm{~mm}$ ) to the cutting base following wounding and cuttings were placed in perlite $(100 \%)$ rooting medium under mist. The rooting percentage, number of roots per cutting and root length were measured 4 weeks after planting. Banding and duration significantly stimulated rooting of leafy softwood cuttings. The highest rooting percentage $(80.0 \%)$ was obtained on cuttings banded for 6 weeks and treated with 5 mM IBA.
\end{abstract}

Great differences in the rooting ability of cuttings exist among species and cultivars. With most species, the careful selection of cutting material from stock plants or containerized plants, management of cuttings and control of environmental conditions during rooting have a significant role on rooting of cuttings (Hartmann et. al., 1997). Stem cuttings of some vegetative rootstocks root so readily that the simplest facilities and care yield high rooting percentages. However, cuttings of some rootstocks root only with difficulty and the rooting rate is very low, even if the environmental conditions are optimal. External application of plant growth regulators, wounding, and environmental manipulation of cuttings result in physiological changes in cuttings and can promote rooting (Couvillon, 1988).

Stock plant etiolation studies have special significance, especially on difficult-to-root species. Reducing irradience levels of stock plants can sometimes enhance rooting of difficult-to-root species. During the etiolation process, entire plants or several branches of a stock plant are covered with black plastic or banded to localize light exclusion pretreatment, excluding light from the portion of a stem that will eventually become the cutting base (Bassuk and Maynard, 1987; Maynard and Bassuk, 1987). Castanea (Bricolti et al., 1994), various forestry plant and shrubs (Hoad

Received for publication 6 Oct. 2003. Accepted for publication 10 Feb. 2004. We thank Douglas Senalik and Ahmet Ipek (Department of Horticulture, University of Wisconsin, Madison, Wis.) for critical reading of the manuscript.

${ }^{1}$ To whom reprint requests should be addressed; e-mail hsgulen@uludag.edu.tr.

${ }^{\mathrm{z}}$ Mean value per rooted cutting. ${ }^{x}$ Not detected.

${ }^{{ }}$LSD value. apple rootstocks. Although the benefits of etiolation or blanching are well documented for propagation of apple rootstocks and some ornamental shrub species (Howard et al., 1988), little work has yet been done on stone fruit species.

Seasonal timing or the period of the year in which cuttings are taken may impact rooting. Although, it is possible to make cuttings of easy-to-root species throughout the year, softwood cuttings of many deciduous woody species taken during spring or summer enhance the rooting percentage. It is reported that leafy softwood cuttings of many difficult-to-root species such as cherries taken during spring and summer usually root more readily than hardwood cuttings (Hartmann and Brooks, 1958; Hartmann et al., 1997).

In nurseries, it is important to find the best conditions for an economic propagation of plants that have commercial importance. Some cherry species are known to be easy propagating by cuttings, while some hybrids are known to be somewhat problematic due to poor rooting (Webster and Schmidt, 1996). In this respect this research was initiated to investigate the effects of banding and IBA application on rooting ability of leafy softwood cuttings of Gisela-5, one of the most popular vegetative rootstocks for cherry growing, which is difficult-to-root by cuttings. Another objective of this study was to determine the effect of timing of taking cutting on the rooting of the cuttings taken in two different periods.

woody ornamental plants like Rhododendron (Maynard and Bassuk, 1987) are propagated rapidly with cuttings using etiolation. Banding has been also used to improve rooting success of a wide range of difficult-to-root woody species and increased cutting production. For example, Sumner (1991) demonstrated that short period of banding on light-grown shoots promoted adventious root formation of difficult-to-root

\section{Materials and Methods}

Banding was accomplished by placing self-adhesive black plastic tape ( $1.5 \mathrm{~cm}$ wide) at the base of new shoots (the future cutting base) when they were 5 to $7 \mathrm{~cm}$ long. Bands were left on the shoots for 6 or 10 weeks and

Table 1. Effects of the banding and IBA treatments on rooting percentage, number of roots per rooted cutting and root length of the leafy softwood cuttings of Gisela-5 taken 6 or 10 weeks after banding.

\begin{tabular}{|c|c|c|c|c|c|}
\hline $\begin{array}{l}\text { IBA } \\
\text { treatment } \\
(\mathrm{mm})\end{array}$ & Banding & $\begin{array}{r}\text { Duration } \\
\text { (weeks) }\end{array}$ & $\begin{array}{c}\text { Rooting } \\
(\%)\end{array}$ & $\begin{array}{l}\text { Roots/ } \\
\text { cutting } \\
\text { (no.) }\end{array}$ & $\begin{array}{l}\text { Root } \\
\text { length } \\
(\mathrm{cm})\end{array}$ \\
\hline \multirow[t]{4}{*}{$\overline{0}$} & No & 6 & $0.0 \mathrm{j}^{\mathrm{y}}$ & $--^{x}$ & --- \\
\hline & Yes & 6 & 9.11 & 1.0 & 0.5 \\
\hline & No & 10 & $0.0 \mathrm{j}$ & --- & --- \\
\hline & Yes & 10 & $0.0 \mathrm{j}$ & --- & --- \\
\hline \multirow[t]{4}{*}{5} & No & 6 & $63.6 \mathrm{~d}$ & 11.3 & 3.4 \\
\hline & Yes & 6 & $80.0 \mathrm{a}$ & 10.1 & 3.7 \\
\hline & No & 10 & $32.0 \mathrm{~g}$ & 5.5 & 2.5 \\
\hline & Yes & 10 & $61.6 \mathrm{e}$ & 9.3 & 2.9 \\
\hline \multirow[t]{4}{*}{10} & No & 6 & $65.0 \mathrm{c}$ & 9.3 & 1.9 \\
\hline & Yes & 6 & $66.0 \mathrm{~b}$ & 11.4 & 3.1 \\
\hline & No & 10 & $21.4 \mathrm{~h}$ & 1.0 & 1.6 \\
\hline & Yes & 10 & $49.5 \mathrm{f}$ & 7.9 & 3.2 \\
\hline \multicolumn{6}{|l|}{ ANOVA } \\
\hline \multicolumn{2}{|l|}{ IBA } & & $*$ & NS & $*$ \\
\hline \multicolumn{2}{|c|}{ Banding } & & * & * & $*$ \\
\hline \multicolumn{2}{|c|}{ Duration } & & $*$ & $*$ & $*$ \\
\hline \multicolumn{2}{|c|}{ IBA $\times$ banding } & & * & NS & * \\
\hline \multicolumn{2}{|c|}{ IBA $\times$ duration } & & $*$ & NS & NS \\
\hline \multicolumn{2}{|c|}{ Banding $\times$ duration } & & $*$ & $0.734^{\mathrm{w}, *}$ & NS \\
\hline $\mathrm{IBA} \times \mathrm{b}$ & duration & & $*$ & NS & NS \\
\hline
\end{tabular}

yValues within column followed by the same letter are not significantly different at $P<0.05$ by LSD.

Ns,"Nonsignificant or significant within column at $P<0.05$, respectively. 


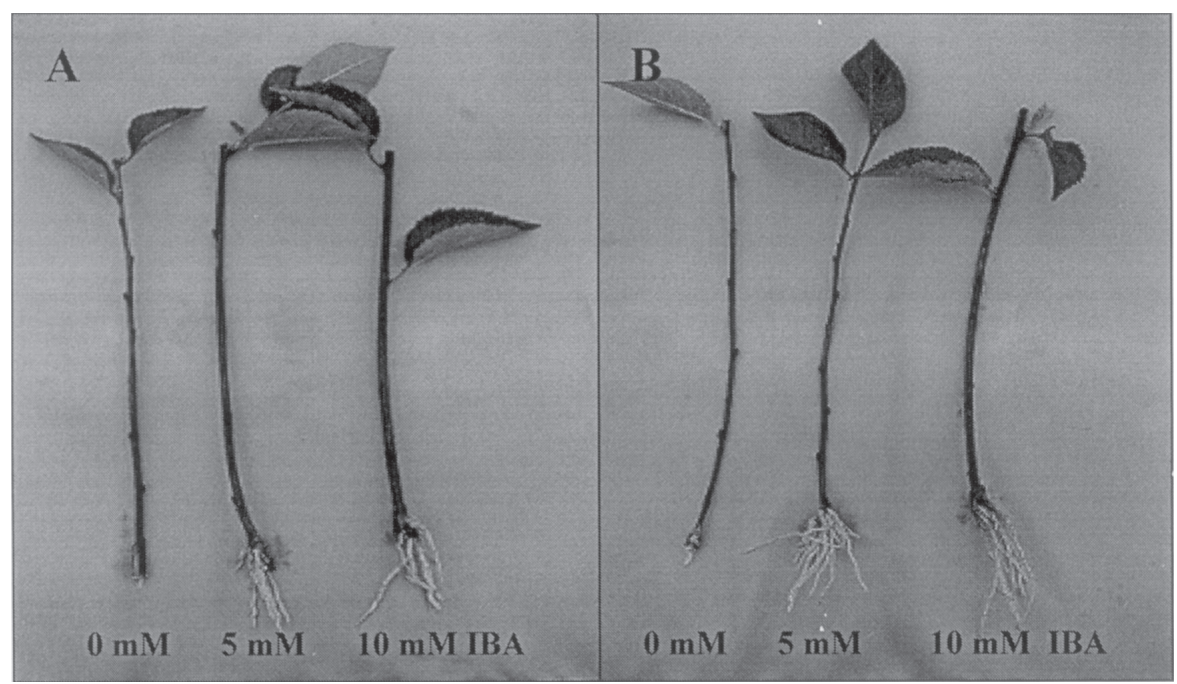

Fig. 1. The effects of banding and IBA applications on rooting of Gisela-5 leafy softwood cuttings taken 6 weeks after banding. (A) Cuttings with no banding. (B) Cuttings with banding.

shoots excised from the stock plant proximal to the banded area. Pooled shoots were put into plastic bag covered with wet canvas, brought to propagation unit. Shoots were cut to a maximal length of 20 to $25 \mathrm{~cm}$ and the lower two to three leaves (depending on the length of internodes) were eliminated. The bands were removed and the cutting base was slit vertical with a sharp grafting knife on three sides for 1 $\mathrm{cm}$, penetrating through the bark and into the wood. The cutting base was dipped for $10 \mathrm{~s}$ in 5 or $10 \mathrm{~mm}$ IBA solution (by volume, $50 \%$ ethyl alcohol: $50 \%$ water) following wounding. After drying, cuttings were placed in perlite $(100 \%)$ rooting medium to a depth of $\approx 10 \mathrm{~cm}$ in the greenhouse rooting bench. Control cuttings ( $0 \mathrm{~mm}$ IBA treatment) were dipped for $10 \mathrm{~s}$ in $50 \%$ ethyl alcohol only. During the rooting, average $28 / 18{ }^{\circ} \mathrm{C}$ day/night temperature and 50000 lux light intensity (16/8, light/dark) were maintained in the greenhouse. In addition, 75\% to $80 \%$ relative humidity was maintained with a mist system ( $10 \mathrm{~s}$ for every $20 \mathrm{~min}$ during the day; $5 \mathrm{~s}$ for every $2 \mathrm{~h}$ during the night). Four weeks after planting, cuttings were removed from the rooting bench, and rooting percentage, average number of roots per rooted cutting and average root length $(\mathrm{cm})$ per rooted cutting were evaluated.

The experiment was arranged in a randomized block design with three replications (15 cuttings per replication). Data were tested by analysis of variance (ANOVA) and mean separation was accomplished by least significant difference (LSD) test at $P<0.05$. BARNES and MSTAT-C computer programs were used for correlation analysis.

\section{Results and Discussion}

Effects of IBA treatment, banding and banding duration on rooting of Gisela-5 cuttings are summarized in Table 1. Rooting percentage changed significantly depending on IBA treatment, banding, and duration. In addition, all the interactions among the treatments were significant. In general, rooting percentage of cuttings banded for 6 weeks was higher than that banded for 10 weeks. The highest rooting percentage $(80.0 \%)$ was observed for cuttings banded for 6 weeks and treated with $5 \mathrm{~mm}$ IBA. Regarding IBA treatments, our data are consistent with a study suggesting $5 \mathrm{~mm}$ IBA application in order to propagate leafy softwood cuttings of cherry rootstocks (Webster, 1996). Strauch et al (1985) also reported that softwood cuttings of cherry hybrids had good potential for forming adventitious roots under mist after 5 mm IBA treatment. Considering the banding, exclusion of light by etiolation or stem banding greatly enhances a stem's sensitivity to auxin (Maynard, 1991, 1992) and stimulates root initiation (Englert et al., 1991). However, banding for 10 weeks decreased the rooting percentage, even in $5 \mathrm{~mm}$ IBA treatment in this study. Shoots banded for 10 weeks were almost 45 to $50 \mathrm{~cm}$ at the time of excising and stock plant was almost at the end of active growing. Strauch et al (1985) achieved the best rooting of cuttings when the shoots on stock plants were at the active growing period. Evidently, rooting percentage of leafy softwood cuttings taken at the beginning of growing season or at the end of spring is higher than that taken in summer in difficult-to-root species (Hartmann et al., 1997).

Regarding the number of roots per cutting, banding and duration had significant effect. In addition, an interaction between banding and duration was observed. However, neither IBA treatment nor any interaction with IBA had significant effect on the number of roots per cutting. As it was shown in Fig. 1, more roots were observed for banded cuttings. Some anatomical and physiological changes can occur in etiolated stem tissue that enhances rooting. Howard and Ridout (1992) concluded that etiolated plant parts were relatively thin stems, which was associated with a net accumulation of dry matter at the cutting base before the first root emerged and during the rooting. In the present study, banding for 6 weeks increased the number of roots per cutting. Duration of banding may play an important role on the accumulation of dry matter that affects root initiation and, consequently, number of roots per cutting. In addition many of the techniques described to enhance rooting potential like severe pruning and blanching, induce in the stock plant juvenile characters and the resulting material is described as rejuvenated (Howard et al., 1988). Rejuvenated character may also increase the number of roots per cutting.

Root length changed significantly depending on IBA treatment, banding and duration. Considering all the treatments, however, the only interaction was observed between IBA treatments and banding. The highest root length $(3.7 \mathrm{~cm})$ was observed for cuttings banded for 6 weeks and treated with 5 mM IBA. Evidently, IBA treatment following banding was suggested for root initiation and further root quality (Howard and Harrison-Murray, 1985). To obtain the maximum root quality, HarrisonMurray and Howard (1982) suggested that normal blanching tapes must be applied close behind the shoot apex while this is actively extending. This may also explain why banding for 6 weeks was more effective.

\section{Conclusions}

The standardized technique presented here can greatly improve rooting of Gisela- 5 softwood cuttings. Rooting percentage and root length changed significantly depending on IBA treatment, banding and duration while number of roots per rooted cutting was affected significantly by banding and duration. Data indicated that the highest rooting response was obtained on cuttings banded for 6 weeks and treated with $5 \mathrm{~mm}$ IBA.

\section{Literature Cited}

Bassuk, N. and B. Maynard. 1987. Stock plant etiolation. HortScience 22:749-750.

Bricolti, S.,A. Fabbri, F. Ferrini, and P.L.Pisani. 1994 Adventious rooting in chestnut: An anatomical investigation. Scientia Hort. 59:197-205.

Couvillon, G.A. 1988. Rooting responses to different treatments. Acta Hort. 227:187-196.

Davies, Jr., F.T. and H.T. Hartmann. 1988. The physiological basis of adventitious root formation. Acta Hort. 227:113-120.

Englert, J.M., B.K. Maynard, and N.L. Bassuk. 1991. Correlation of phenolics with etiolated and light-grown shoots of Carpinus betulus stock plants. Comb. Proc. Intl. Plant Prop. Soc. 41:290-295.

Harrison-Murray, R.S. and B.H. Howard. 1982 Preconditioning shoots for rooting, p. 57-60. Rpt. E. Malling Res. Sta. 1981.

Hartmann, H.T. and R.M. Brooks. 1958. Propagation of Stockton Morello cherry rootstock by softwood cuttings under mist sprays. Proc. Amer. Soc. Hort. Sci. 71:127-134.

Hartmann, H.T., D.E. Kester, F.T. Davies, Jr., and R.L. Geneve. 1997. Techniques of propagation by cuttings, p. 329-391. In: H.T. Hartmann, D.E. Kester, F.T. Davies, Jr., and R.L. Geneve (eds.). Plant propagation: principle and practices. Prentice-Hall.

Hoad, S.P. and R.R.B. Leakey. 1996. Effects of pre-severance light quality on the vegetative propagation of Eucalyptus grandis W. Hill ex Maiden: Cutting morphology, gas exchange and carbohydrate status during rooting. Trees 10(5):317-324.

Howard, B.H. and R.S. Harrison-Murray. 1985 Optimizing the rooting response of stem cut- 
tings to applied auxin, p. 101-111. In: Growth regulators in horticulture. Brit. Plant Growth Monogr. 13.

Howard, B.H. and M.S. Ridout. 1992. A mechanism to explain increased rooting in leafy cuttings of Syringa vulgaris 'Madame Lemoine' following dark-treatment of the stock plant. J. Hort. Sci. 59:131-139.

Howard, B.H., R.S. Harrison-Murray, J. Vasek, and O.P. Jones. 1988. Techniques to enhance rooting potential before cutting collection. Acta Hort. 227:176-186.

Maynard, B.K. 1990. Comparisons of stock plant etiolation with traditional propagation methods. Comb. Proc. Intl. Plant Prop. Soc. 40:517-523.
Maynard, B.K. 1991. Stock plant etiolation and stem banding effect on the auxin dose-response of rooting in stem cuttings of Carpinus betu lus L. 'Fastigiata'. J. Plant Growth Regulat. 10:305-311.

Maynard, B.K. 1992. Stock plant etiolation, shading, and banding effects on cutting propagation of Carpinus betulus. J. Amer. Soc. Hort. Sci. 117:740-744.

Maynard, B.K., and N.L. Bassuk. 1987. Stock plant etiolation and blanching of woody plants prior to cutting propagation. J. Amer. Soc. Hort. Sci. 112:273-276.

Reuveni, O. and M. Raviv. 1981. Importance of leaf retention to rooting avocado cuttings. J. Amer. Soc. Hort. Sci. 106:127-130.
Strauch, H., M. Roth, and W. Gruppe. 1985. Rooting softwood cuttings of interspecific cherry hybrids and Prunus species by mist propagation. Acta Hort. 169:371-379.

Sumner,P.E. 1991. Stembanding enhances rooting and subsequent growth of M.9 and MM.106 apple rootstock cuttings. HortScience 26(11):1368-1370.

Webster, A.D. 1996. Propagation of sweet and sour cherries, p. 167-202. In: A.D. Webster and N.E. Looney (eds.). Cherries: Crop physiology, production and uses. CAB Intl. Wallingford, U.K.

Webster, A.D. and H. Schmidt. 1996. Rootstocks for sweet and sour cherries, p. 127-166. In: A.D. Webster and N.E. Looney (eds.). Cherries: Crop physiology, production and uses. CAB Intl. Wallingford, U.K 